and understanding, and she translated these impressions into her writings.

As a young woman, she travelled to Nazi Germany with her life-long friend Louise Holborn. In 1948-49 she went on a round-the-world trip visiting Commonwealth countries including South Africa where she remained for three months driving herself in a specially adapted car as she criss-crossed the country. In the 1950s on the eve of independence for many African countries she again travelled extensively on the continent, and her detailed accounts of her meetings and impressions will some day prove to be an invaluable source of information for researchers on this crucial period in African history.

Gwendolen Carter was a great teacher. She shared her knowledge fully with her students, and she generously opened her home to them for meals, seminars, and receptions. But she also had high academic standards and, if these were not met, she had no hesitation in letting students know where they stood. She helped countless students from Africa adjust to the demands of life in the United States and in many instances was responsible for their coming to America. A number of her students are now at universities or in government positions in Africa.

It has been a great privilege for me to know Gwendolen Carter and to work with her on several projects. Her sense of freshness and excitement nurtured and sustained ideas. She was a woman of deep convictions and real courage. I can still hear her voice on her return from South Africa at the age of eighty after she had been held in detention by the South African police and interrogated. "I simply refused to talk with them. I just kept demanding to see the American arıbassador."

I honor Gwendolen Carter as a teacher, a researcher, a personal friend, and a pioneer. She was a woman of fearless integrity and intrepid mind.

Patrick O'Meara Indiana University

\section{R. Taylor Cole}

R. Taylor Cole, James B. Duke Research Professor Emeritus at Duke University, died peacefully in his sleep on the morning of May 15 , 1991, at the age of eighty-five. Although slowed to some degree by the usual infirmities of age, he led an active social and professional life until the end, having worked in his office and dined with friends the preceding day.

He was born Robert Taylor Cole, on September 3, 1905, in Bald Prairie, Texas, the son of Robert Wiles Cole and Elizabeth Taylor Cole. He was the oldest of six children, having four brothersThomas, Estes, Fred, and Lutherand one sister-Margaret.

In 1921, he entered the University of Texas, where he pursued studies in the fields of history, government, and law. He received his B.A. degree there in 1925 and his M.A. degree in 1927. During his years at Austin, Taylor formed lasting friendships with a number of other students who were to enter the profession of political science. This group, which was sometimes referred to as the "Texas Mafia,' included J. Alton Burdine, Emmette Redford, Roscoe Martin, Luther Evans, Francis Wilson, and V. O. Key, Jr. In 1929, he joined three other Texans-Burdine, Redford, and Campbell Beard-in the doctoral program at Harvard University. He studied there under Carl J. Friedrich, Samuel Eliot Morison, Edwin F. Gay, Charles H. McIlwain, B.F. Wright, and Arthur N. Holcombe. He set sail for Germany in 1933 to study the German Labor Front and was placed by good fortune at the dinner table with Anne C. ("Nan") Berton, whom he married in 1935 . He received his doctorate from Harvard in 1936.

He held the positions of instructor, assistant professor, and associate professor at Louisiana State University from 1926-29, and from 1931-33, where he studied some of that state's distinctive political institutions, enjoyed fishing in Cajun country and duck hunting in the marshes below Houma, and observed with fascination the career of Huey Long. He also held instructorships at Harvard in 1930-31 and 1934-35; and he served there as a resident tutor in
Kirkland House. In 1935, he accepted an appointment as assistant professor of political science at Duke University. He spent the rest of his life as a member of the Duke faculty, as associate professor from 1937-45, and as professor after 1945. In 1953, he became one of the first incumbents of the newly established named chairs at Duke, receiving the title of James B. Duke Professor of Political Science.

Taylor Cole's research interests centered around the institutions of fascist and post-fascist regimes, bureaucracy, and federalism. In later years, his interests expanded to include comparative higher education and political development. Geographically, he developed particular expertise in the areas of German and Italian politics and in the politics of the Commonwealth countries, especially Canada and Nigeria. In addition to numerous articles and occasional reports on these topics, he was author or co-author of eight books, including Responsible Bureaucracy (Duke U. Press, 1949), European Political Systems (Alfred A. Knopf, 1961), The Nigerian Political Scene (Duke U. Press, 1962), and Politics and Government in the Federal Republic of Germany (Berg Publishers, 1984). He considered his research and publications a vocation and a pleasure, and he continued to be actively engaged in his scholarly pursuits as an emeritus professor. He also served as a consultant to foundations, especially the Ford Foundation on several occasions, and to foreign governments on problems of bureaucratic development and educational policy.

Taylor Cole was a central and important figure in both the American Political Science Association and the Southern Political Science Association. He served as editor of the Journal of Politics from 1945-49 and he was elected as president of the Southern Political Science Association in 1951. He then deployed his editorial skills on the national level, serving as editor of the American Political Science Review from 1950-53. He was chosen to be president of the American Political Science Association in 1958, taking some pride in being the first person from a southern university to be so honored. He particularly enjoyed his 
work as one of the founding members of the Committee on Comparative Politics of the Social Science Research Council, calling that body "the most stimulating group with which I was ever professionally associated."

During the Second World War and the years following, he took leave from Duke to serve the government in several capacities. He served with the Overseas Branch of the Office of War Information and then with the Office of Strategic Services, headed by Colonel, later General, "Wild Bill" Donovan. In the summers of 1948 and 1949, he served as consultant to General Lucius Clay on the process of German redemocratization. For his contributions in these areas, he was awarded the Medal of Freedom in 1945 and the highest civilian commendation of the Federal Republic of Germany, Das Grosse Verdienstkreuz, in 1986.

In 1960, Duke University was experiencing an unsettled administrative situation, and Professor Cole was asked by acting president Deryl Hart to serve in an interim capacity as provost of the university. He quickly established himself as a skilled and diplomatic administrator, and the incoming president in 1963, Douglas M. Knight, asked him to continue in that capacity. His "interim" appointment eventually stretched until 1969 . During his tenure as the chief academic officer of the university, he provided crucial leadership in bringing about the integration of the university; and his calm, moderate, and empathetic approach was equally crucial in bringing Duke University through its period of student unrest in the late 1960's as a stronger rather than a weaker institution.

$R$. Taylor Cole received many honors in his lifetime, and deservedly so. In addition to the offices and awards previously mentioned, he was elected to membership in the

American Academy of Arts and Sciences. He received the Southern Political Science Association's Manning J. Dauer Award for distinguished service to the profession of political science. He was one of the first recipients of the Duke University Medal for Distinguished Meritorious Service. And the university last year named the Faculty Commons dining room in his honor. As these awards testify, this was a man who served his discipline, his university, and his country with diligence and distinction.

It was, however, who he was rather than what he did that made Taylor so special. He was in many respects a walking Hegelian synthesis, reconciling seeming opposites in his character and behavior in a way that made him both memorable and delightful.

He was a man of legendary graciousness. But to those who knew him well he was equally renowned for his stubbornness. Actually, this was only an apparent contradiction, for he was most stubborn about being gracious. When a former colleague came to Duke for his job interview, acquaintances at Harvard bet him ten dollars that he could not get Taylor Cole to enter a doorway ahead of him. He foolishly accepted that challenge and of course had to pay up upon his return to Cambridge. I'm sure that had he not eventually relented and walked ahead of Taylor, the two of them would be standing there still. Similarly, when Taylor suffered a heart attack last year on a bus from Austin, Texas, to Dallas for a flight back to Durham, he completed his journey home before registering any complaint. $\mathrm{He}$ did so in part, I suspect, because this was home and he wanted to be here with his friends if he were to be hospitalized. But in part it was because it would have violated his courtly instincts to bother someone with a problem so minor as a coronary blockage. When you heard such a report, you wanted to remonstrate with Taylor, but you realized it was no use. He was just being who he was.

Taylor was a man of extraordinary competence in important matters, but he was endearingly semi-competent in some of life's lesser and more common endeavors. He could cut to the heart of any argument. He could provide sage advice on matters of state and public policy. He could edit a journal with astute judgement and an even hand. He could build an academic department. He could help lead a university through major transitions and through troubled times. But his sartorial choices could on occasion drive his female friends to distraction. His housekeeping efforts, though sincere, were such that he no doubt would have disappeared long ago beneath piles of books, papers, personal belongings, and memorabilia were it not for the intervention of housekeepers and friends. And he never, ever, mastered the art of vehicular navigation. He confessed to me recently that one of his earliest driving efforts had ended in disaster. Sent by his father to fetch some arriving house guests, Taylor drove them into the back of a wagon. No one who rode with him would have been surprised to hear this story, least of all Taylor's long-time colleague John Hallowell, who was riding with Taylor one time when he ran over a gas pump. It was a sure sign of God looking out for one of his most cherished creations that Taylor was able to die peacefully in his own bed after 70 years behind the steering wheel.

Taylor was a man of great worldly wisdom and sophistication. But he retained all his days the freshness and innocence of childhood. The particular joy of Taylor's company was that you could learn so much from his knowledge and insight while at the same time being led to experience the world, even with all its miseries, as the remarkable and enchanting place that it is. Aristotle claimed that knowledge originates in wonder, and Taylor's learning always drew nourishment from that source. It can truly be said of him that he gradually became aged but he never grew old.

Taylor's demeanor combined great dignity with an expansive lightness of spirit. All who came into his presence were instantly aware that he possessed what the ancients called gravitas. He was serious about serious things and profound in his concerns and convictions. But he always had a sparkle in his eye and fun in his heart. He had a quick wit and a ready laugh. With all his achievements he never took himself too seriously or assigned great importance to what he did. He called his autobiography his "recollections" because he thought "memoirs" sounded too pretentious. To be with Taylor was to know what the communion of saints is all about-not a society of the pious and sober, but a company of the sweet of spirit and the light of heart. 
Because of his magnanimity, his kindness, and his warmth, Taylor was a favorite of children. On his first visit to our home, my older son-then about four-wound up happily and voluntarily ensconced in Taylor's lap. I can remember no one else receiving this voiceless accolade. But with the sure intuition of a child, my son quickly had realized that here was a worthy companion and someone who could be trusted implicitly. In like manner, my two-year old son, who is Taylor's namesake, grabbed Taylor on a more recent occasion, seated him on the sofa, and conversed with him at length about all manner of his two-year old concerns. He knew that he had found an appreciative listener and a person you could confide in. Taylor's appeal to children was all the more remarkable because they were almost opaque to his understanding. Perhaps because he had no children himself, he haddespite his solicitude toward themalmost no grasp of their developmental stages and cognitive limitations. I was charmed and bemused to watch Taylor a few months ago earnestly attempt to explain to his two-year-old guest the significance of some of his African mementoes. "This artifact, Taylor," he said to my son, "came from the Yoruba people in the country of Nigeria." Impressed but understandably nonplussed, my son responded with a respectful "Oh!'" I'm sure that the senior Taylor in this exchange, ever the optimist about the intellect of his students, was confident that his instruction had been fully absorbed. I didn't have the heart to tell him otherwise or to dissuade him from his futile disquisitions. Besides, young Taylor clearly felt honored by the attention even if he was at a loss about its import.

Taylor Cole was one of Aristotle's spoudaioi, a wise and prudent man who knew the human good and was skilled in its attainment. He was one of Jefferson's natural aristocrats, a man born equal who achieved eminence through his unusual talents. He was one of Burke's "great oaks," one of those towering presences "that shade a country and perpetuate benefits from generation to generation."

Despite his greatness, he never lost his common touch and down to earth sensibility. Nan, his late beloved wife, called him "Buddy." And that he was: a friend for the ages, a constant joy and treasure to all of us fortunate enough to know him. It was one of the happiest ironies of his existence that Taylor so relished playing the role of "devil's advocate." For, as everyone well knew, he was always on the side of the angels.

Thomas A. Spragens, Jr. Duke University

\section{Roger Hansen}

With the death of Roger Hansen, the Third World lost a fervid spokesman. For most of his career, Roger attempted to explain the Third World to the First, and vice-versa. He empathized with the comparative powerlessness of the Third World and with the travails of its individual states, like Mexico. He saw poverty as an unacceptable human condition that was partly the responsibility of everyone in the international system, if not as to cause, then certainly as to elimination. As a political analyst, he recognized that behind economics stands politics. In this he quintessentially distinguished himself from the Marxists in understanding and in ethos.

Roger Hansen was a liberal. He was a liberal in the old sense, not a neo-liberal, or a neo-realist, but an old-style, unreconstructed liberal. In analysis, and in debate, which he loved, he was shrewd and responsible enough to separate his own personal views from the subject he assessed. But the evidence is plain. He wrote from a strong liberal ethos, believing that this tortuous in-between position was the only valid one for a society and for an international system that wanted long-term stability and peace.

In Beyond the North-South Stalemate, Roger Hansen wrote like the well-educated, affluent but sensitive defender of Third World perspectives that he was. "It is time for the North to make a serious bid for a more constructive set of relationships with the developing countries before the still controlled conflict escalatesperhaps more accurately degenerates-into a "negative sum" game in which both sides pay a heavy price for their lost opportunities"' (p. 9).

What gave Hansen's message punch was that he was something of an insider as well as an intellectual and an academic. He was a former senior staff member of the National Security Council, a senior fellow of the Overseas Development Council, a member of the Council on Foreign Relations, a Rhodes Scholar, a member of the Cosmos Club. When he spoke, much of Washington listened. So did the press. Here was a political scientist with the reach to extend beyond the academic community, but still to write from within it.

Yet the United States and the world were changing. Like a storm, the Reagan Revolution swept into Washington. Out went the results of the Third Law of the Sea Conference, the New International Economic Order, and larger programs of foreign economic assistance. In came the heightened East-West confrontation, big defense programs, tough foreign policy rhetoric, and muscle in foreign policy comportment. Yet in economic terms, the United States was also relatively weaker. Less had to do more. These were tough times for liberals, and, intellectually, this was a tough time for Roger Hansen. He saw the international political world moving in a direction he thought wrong. But the wave of conservatism swept over him and made his message sound a bit dated, a bit outof-step. Hansen was troubled and increasingly indisposed.

History has not yet determined whether the vision that Roger Hansen and like-thinkers possessed was right or whether his intellectual and political opponents were more correct. But what is without doubt, as his obituary in the New York Times attests, is that Roger was a player in the best sense of the field of international relations, in the classroom, in the debates at the Nitze School of Advanced International Studies (often opposite Robert W. Tucker, his much-respected conservative friend) where he held a chair, or in the pages of Foreign Affairs and other journals where he was a popular contributor.

For most of us, Roger Hansen will 